\title{
April 1964
}

\section{The Journal of}

\section{Laryngology and Otology}

\author{
EDITED BY \\ G. H. BATEMAN \\ ASSISTANT EDITOR \\ LIONEL TAYLOR

\section{Contents}

The AEtology OF the Posterior PHaRyngeal DIVERTICULUM: A CINERADIOGRAPHIC STUDY

The Administration of Chemotherapeutic Agents in the Treatment of Advanced Head and Neck Cancer

STAPEDECTOMY

Cholesteatoma: The "Vein Graft" Approach.

G. M. ARDRAN, F. H. KEMP and W. S, LUND

Peter Clifford

J. A. KerSLEy and A. J. GRAY

DAVID F. AustriN and GoRDON D. L. SMYTH

THE Long Process of the Incus

Fixed Stapes or Interrupted Ossicular Chain? G. D. L. SмYтн -

Francis Bauer

AN X-RAy Microscopic Study of the Mineral Distribution IN NORMAL AND OtOSCLEROTIC StAPES

J. A. Clarke

Clinical Records-

An Unusual Nasal foreign Body .

R. MitLer

AN Impacted SPHerical Foreign Body in the UPPER END OF CEsophagus fOR FIVE WEEKS

D. K. Gosavi

MYRINGOPLASTY: PROCEDURES, TECHNIQURS, RESULTS

Procedures, TechNiques,

J. A. HARPMAN

Genkral Notes

London

Headley Brothers

109 Kingsway $\mathrm{WC}_{2}$ 


\title{
The Journal of \\ Laryngology and Otology
}

(FOUNDED in 1887 by MORBLL MACKENZIE and NORRIS WOLFENDEN)

\author{
EDITED BY \\ G. H. BATEMAN
}

ASSISTANT EDITOR

LIONEL TAYLOR

1. Original articles which have not been published elsewhere are invited and should be sent to the Editor. They are considered for publication on the understanding that they are contributed to this Journal solely. Reproduction elsewhere, in whole or in part, is not permitted without the previous written consent of the Author and Editor and the customary acknowledgement must be made.

2. Manuscripts should be typewritten, on one side only of the paper, and well spaced. Captions to illustrations should be typed on a separate sheet and sent at the same time as original photographs, etc.

The Harvard system of recording references should be used, e.g. GrREN, C., and Brown, D. (I951) J. Laryng., 65, 33. Abbreviations of Journals should follow the style recommended in World Medical Periodicals, published by World Health Organization, 1952.

It is most important that authors should verify personally the accumcy of every reference before submitting a paper for publication.

3. Galley proofs and engraver's proofs of illustrations are sent to the author. Corrections, which should be kept to a minimum, must be clearly marked, and no extra matter added. Proofs should be returned within 5 days.

4. Illustration blocks are provided free up to the limit of fro per article; beyond this authors are expected to pay half the cost. Coloured illustrations will be charged in full to authors.

Blocks will normally be held by the Printers for three years after which they will be destroyed. Any author who has borne a part of the cost of his blocks is entitled to have these returned to him, but a request for this must be sent within three years of the appearance of the article, to HEADLEY Brothrers, rog Kingsway, London, $\mathrm{WC}_{2}$.

5. Orders for reprints must be sent when returning galley proofs, and for this purpose special forms are supplied.

6. Authors of original communications on Oto-Laryngology in other journals are invited to send a copy, or two reprints, to the Journal of Laryngology. If they are willing, at the same time, to submit their own abstract (in English, French, Italian, or German) it will be welcomed.

7. Editorial communications may be addressed to THE Eorror, Journal of Laryngology, c/o Hradlex Brothers, 109 Kingsway, London, WC2.

8. The annual subscription is five guineas sterling (U.S.A. \$15) post free, and payable in advance.

9. Single copies will be on sale at $12 \mathrm{~s}$. $6 \mathrm{~d}$. each; copies of parts up to Vol. LXIII which are available may be purchased at $78.6 \mathrm{~d}$. each.

10. All subscriptions, advertising and business communications should be sent to the publishers, Headlex Brothers, rog Kingsway, London, WV 2 ,

\section{United States of America}

Orders for this Journal may be sent through local bookseller, or to Stechert-HAfNer, INC., 31-33 East Ioth Street, New York, or direct to the publishers, Hradley Brothers, iog Kingsway, London, WC2, England. (1) Journal of Laryngology and Otology, $19^{64}$ 


\section{CONTENTS}

PAGE

The £tiology of the Posterior Pharyageal Diverticulum:

A Cineradiographic Study. G. M. Ardran, F. H. Kemp and W. S. Lund (Oxford) . . . . . . . . . 333

The Administration of Chemotherapeutic Agents in the Treatient of Advanced Head and Neck Cancer. Peter Clifford (Nairobi) . . . . . . . . . $35^{\circ}$

Stapedectomy. J. A. Kersley and A. J. Gray (Preston) . . . 374

Cholesteatoma: The "Vein Graft" Approach, David F. Austin and Gordon D. L. Smyth (Memphis, Tennessee) 384

The Long Process of the Incus. G. D. L. Smyth (Belfast) . . 400

Fined Stapes or Interrupted Ossicular Chain? Francis Bauer (Liverpool) . . . . . . . . . . . . 408

Ax X-ray Microscopic Study of the Mineral Distribution in Normal and Otosclerotic Stapes. J. A. Clarke (Glasgow)

Clinical Records-

An Unusual Nasal Foreign Body. R. Miller (Glasgow) . 425

An Impacted Spherical Foreign Body in the Upper End of Cesophagus for Five Weeks. D. K. Gosavi (India) • $4^{28}$

Myringoplasty: Procedures, Technigues, Results. J. A. Harpman (Warwick) . . . . . . . . . 43I 


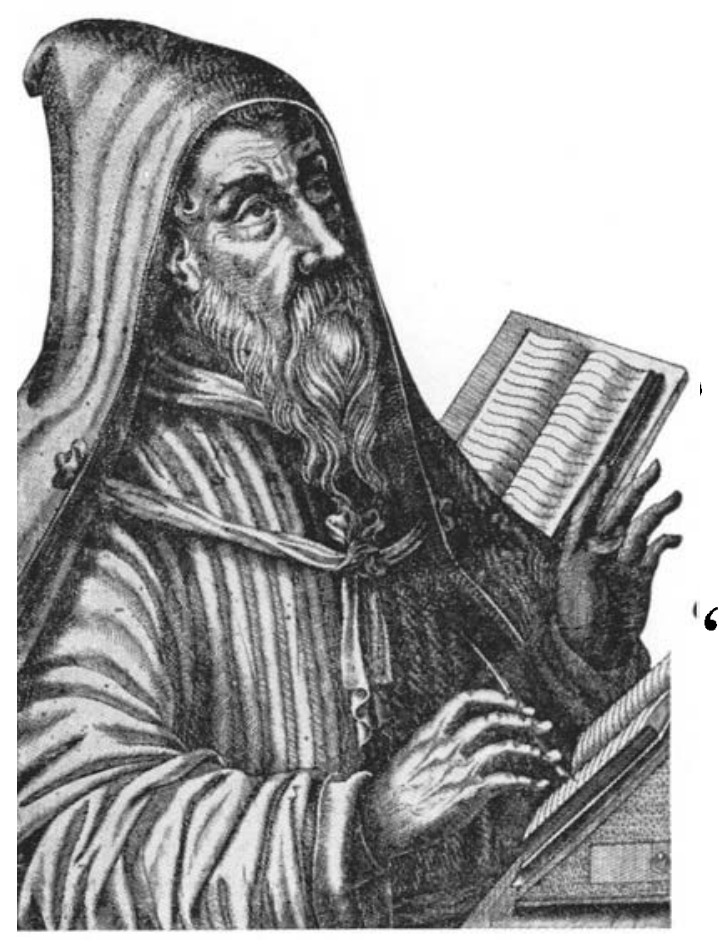

\section{'Audi} partem alteram'

St. Augustine

Fifteen hundred years ago, St. Augustine advised his readers to " hear the other side." Today, your patients with a hearing problem will welcome the same advice from you. Just mention Ingrams.

Ingrams can help your patients to " hear the other side," for they do not represent any one manufacturer and are thus able to give completely impartial advice about hearing aids.

Ingrams help your patient to choose from twenty-six different makes. This is the largest selection in the country - and some of the most modern aids are exclusive to Ingrams.

This is why you, like so many E.N.T. Specialists, can confidently advise your patients to hear the full story from Ingrams before they buy a hearing aid.

\section{INGRAMS}

THE INDEPENDENT HEARING AID CONSULTANTS

2 SHEPHERD STREET, SHEPHERD MARKET, LONDON. W.1 


\section{AND}

NOW

\section{FOR DECONGESTION WITH ANALGESIA}
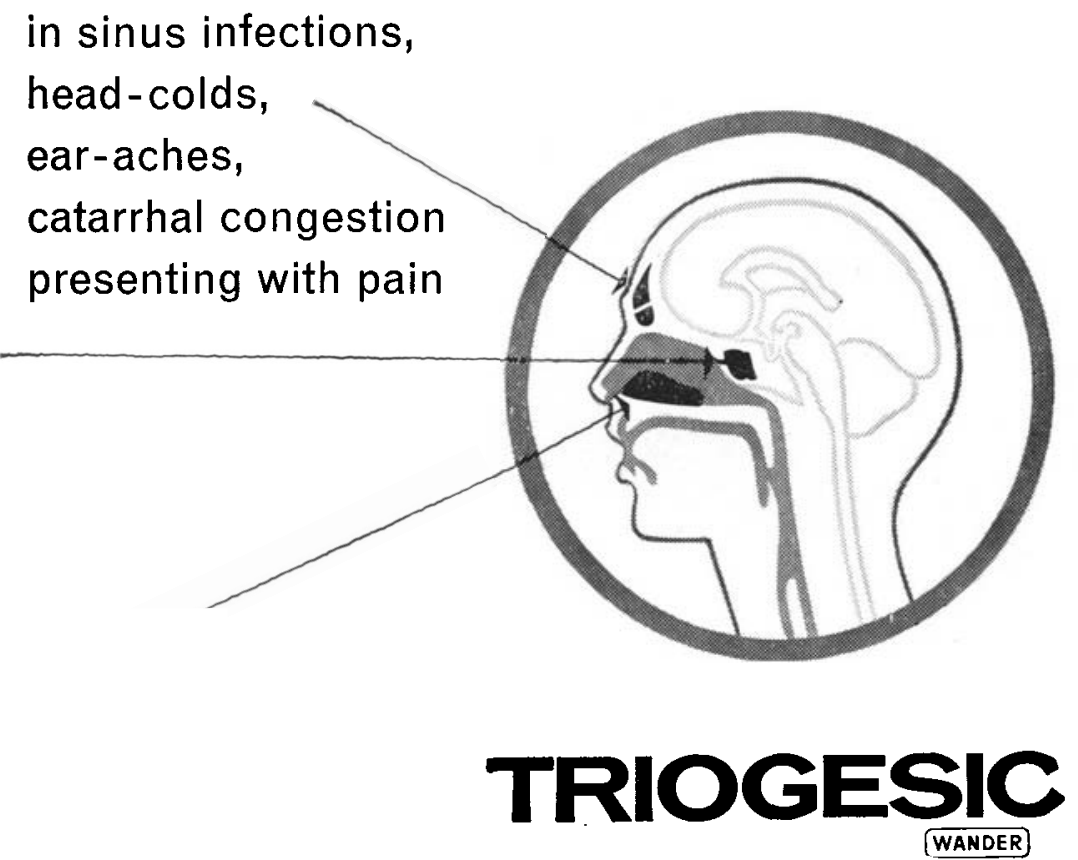

FORMLLA PER TABLET Triominic'. . . 25 ma. P.1. Paracetamol. ...500 $111 \mathrm{~g}$ per + inl. suspension 'Triominic'. . . . 12.5 mg. P.1. Paracetanoi . . . 250 nig. Trioninie' contains $50 \%$ phenylpropanolimine-JICl, $25 \%$ meprrumine maleate and $25 \%$ pheniramine naleate. DOSAGE Adults: 1 Tablet every three to four hours. children: 1 teaspoonful every three to four hours

PACKS \& BASIC N.H.S. PRICES 30 Tablets $3 / 6$ 4 fl. oz. Suspension $3 / 6$
'Triogesic' gives prompt symptomatic relief by associating the established decongestant with antihistaminic actions of 'Triominic' with the reliable and safe analgesic action of paracetamol.

'Triogesic' is available both as scored tablets and in flavoured suspension.

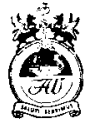

A. WANDER LTD.

42 Upper Grosvenor St., London W.1

Please mention The Journal of Laryngology and Otology when replying to advertisements 


\section{A NEW INSTRUMENT BY KEELER}

\section{The Hallpike Operating Headlamp}
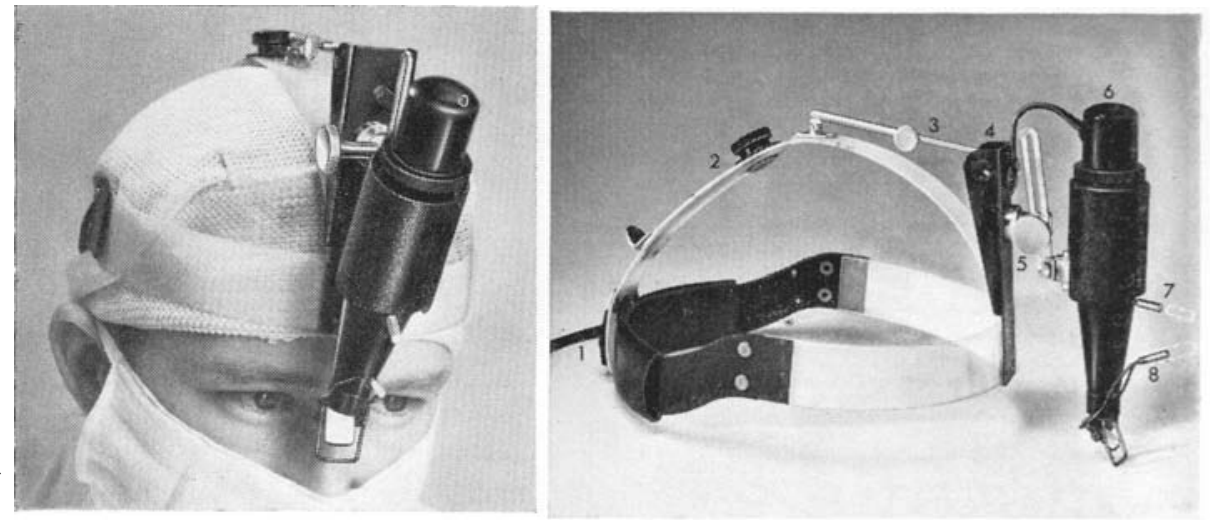

This new Operating Headlamp has been based upon designs and experimental constructions put at our disposal by Mr. C. S. Hallpike, F.R.C.S., F.R.S., of the Otological Research Unit, Medical Research Council, at the National Hospital, Queen Square, and provides the high performance and novel design associated with many Keeler instruments.

The optical system, with its 6 volt 18 watt lamp, is made of light-weight materials and incorporates a heat absorbing filter. It projects, at a convenient working distance, a brilliant and homogeneous circle of light of $65 \mathrm{~mm}$. diameter which may be reduced to $12 \mathrm{~mm}$. by means of a built-in iris diaphragm.

The location of the reflector between the surgeon's eyes ensures that his visual axes lie very close to the light beam. In this way it provides for very satisfactory optical penetration when working in small narrow-necked cavities.

\section{FEATURES}

(1) Convenient screw adjustment for fibre/polythene headband.

(2) Adjustable "over-band" for increased comfort during long operations.

(3) Fully adjustable support strut for maximum rigidity of optical system.

(4) Convenient finger grips for removal of headlamp.
(5) Vertical and angular adjustment of lamp unit, with positive locking action.

(6) Pre-centred, compact filament, $6 \mathrm{v}$. 18 watt lamp.

(7) Iris diaphragm control, with removeable sterilizable sleeve.

(8) Control knob, with sterilizable sleeve, for adjustment of mirror angle and lateral rotation of lamp.

Please mention 1 be Journal of Laryngology and Utology when replying to advertisements 


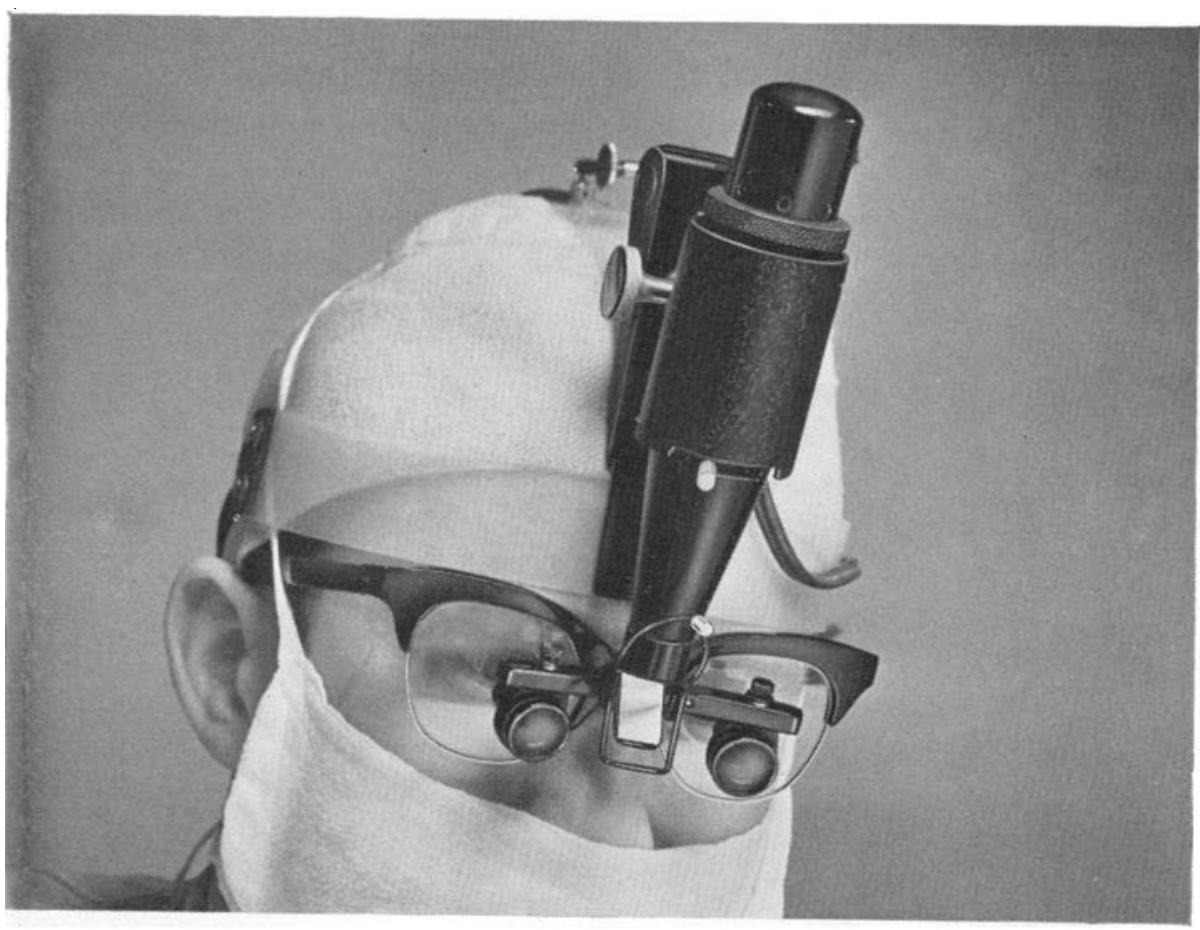

Special emphasis has been placed on the use of the Hallpike Headlamp with the well-known Keeler Magnifying Spectacle. The illustration above clearly demonstrates the complementary nature of the two, offering the surgeon intense illumination with crisp definition up to $5 x$ magnification (see table, right). Because the reflecting mirror, with its wide range of adjustments, can be placed between the surgeon's eyes in line with the visual axes, optimum performance and minimum shadow can be achieved easily. This is particularly important for illumination through a narrow orifice.

When wearing Magnifying Spectacles the surgeon should be able to change rapidly, and it may be repeatedly, from magnified to unmagnified vision. With this new Headlamp the surgeon himself can adjust the light patch with great ease and accuracy not only below the telescopes but also above them. This is a point of particular importance when operating upon or examining a sitting patient. Further details gladly given on request.

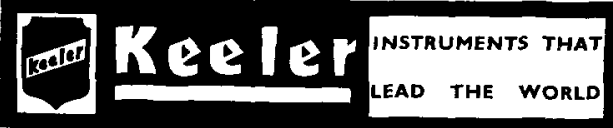

39 Wigmore St., London, W.I. Tel. WELbeck 8512

P'ease mention The Jourral of Lorygology aud Otology when replying to advertisements 


\section{Elliott - UniBristol}

\section{ULTRASONIC SURGICAL THERAPY EQUIPMENT}

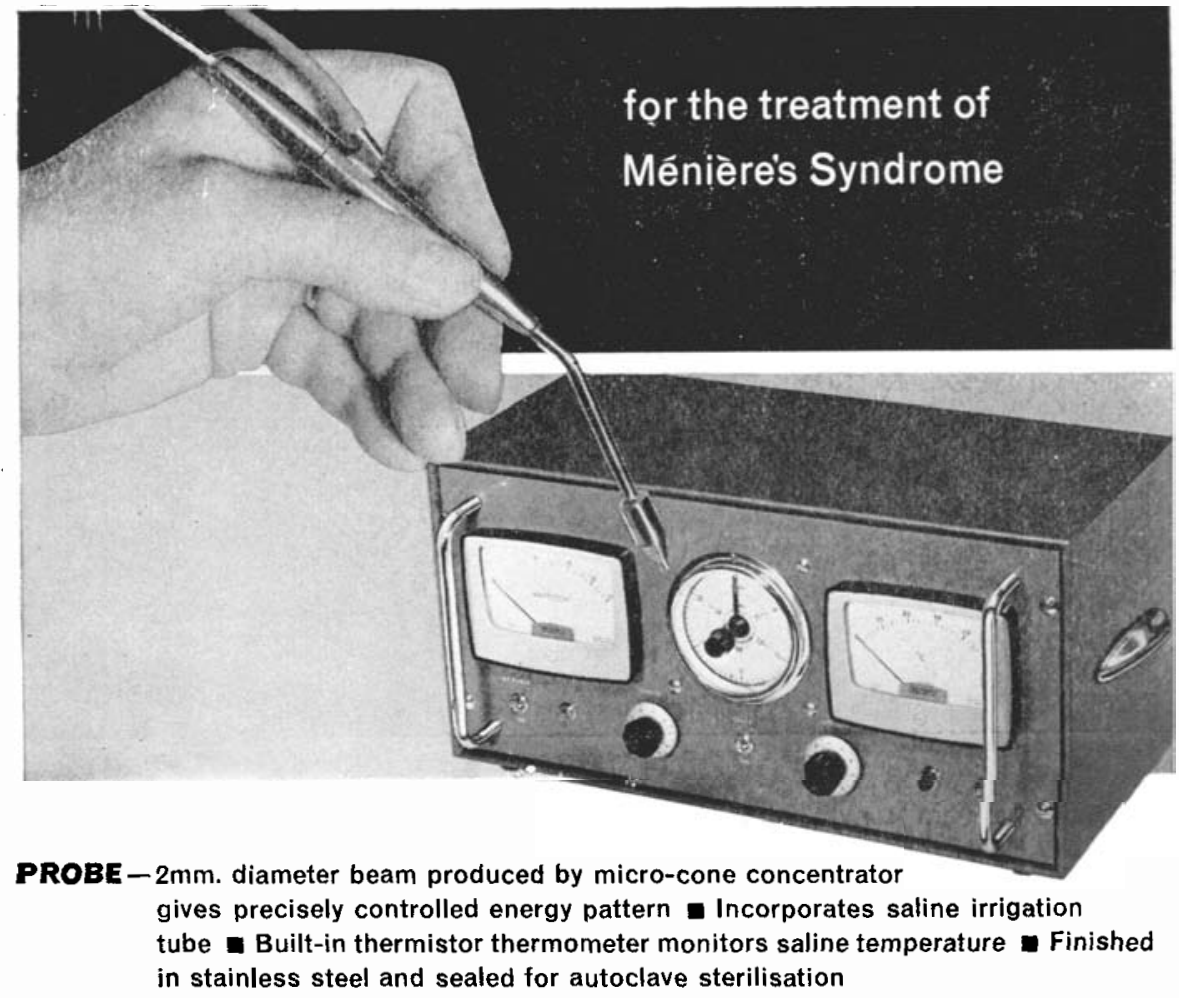

GENI:RATOR-Output variable-(meter indicates in Acoustic Watts $/ \mathrm{cm}^{2}$ )

- Nominal frequency $3 \mathrm{Mc} / \mathrm{s}$ (tuning facility provided)

- Incorporates 60-minute manual re-set timing clock

ACOUSTIC BALANCE-an acoustic radiation balance is provided for calibration of energy output

The Elliott-UniBristol Ultrasonic equipment is based on a design due to the Physics Department of the United Bristol Hospitals and developed in conjunction with the surgeons of the ENT Department

\section{ELLIOT MEDICAL AUTOMATION LTD}

Medical Equipment Division

97 Maidstone Road, Rochester, Kent

EA A Member of the Elliolt-Automation Group Chatham $44824 / 5$

Please mention 'The Journal of Laryngology and Otolog' when replying to advertisements 


\section{ONLY A M PLIVOX provides a complete audiometric service!}

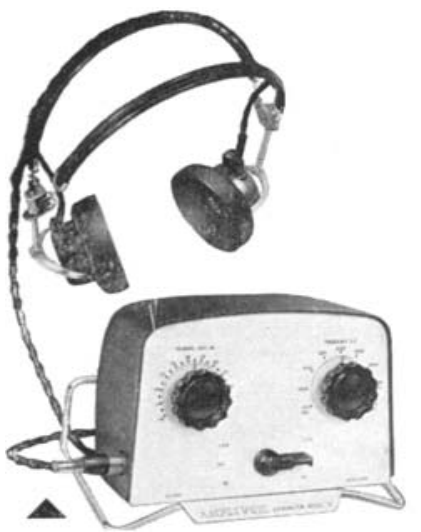

Transistor Audiometers

for the school screening service, ward use, etc.

Speech Audiometry Equipment

via records and tape, including new attachment for use with tape recorders.

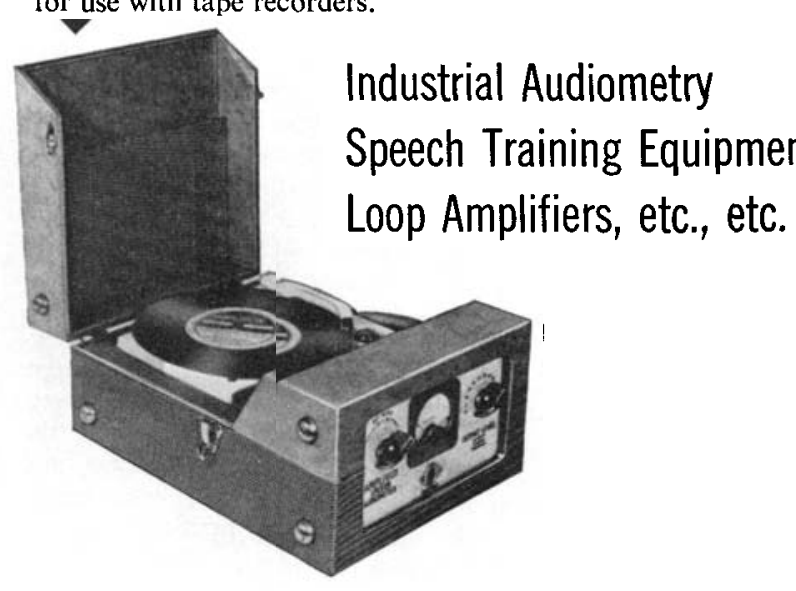

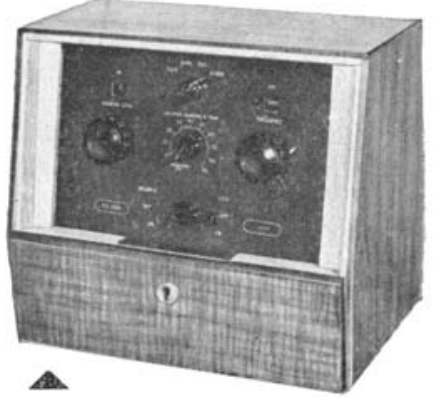

Clinical Audiometers with narrow band masking for the highest accuracy and extended resolution. Audiometer Booths for ideal testing conditions in Hospitals, Clinics, Factories. Standard and special sizes available.

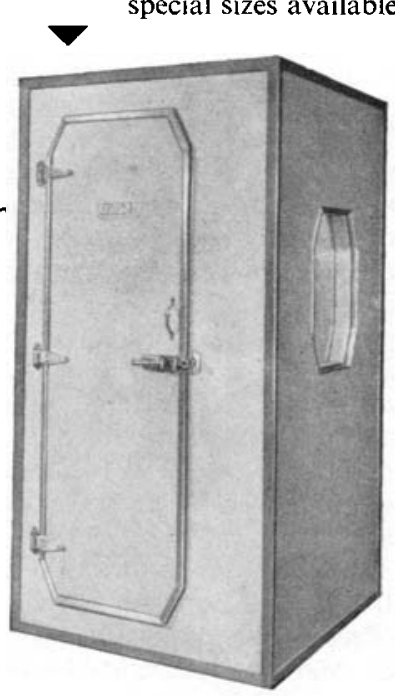

PLUS An efficient and speedy calibration service

Please write for technical AMPLIVOX LTD

literature covering your needs 80 New Bond Street London, W1 Tel : HYDe Park 9888

Please mention The Journal of Laryngology and Otology when replying to advertisements 


\section{THE LARYNGOSCOPE}

A Monthly Journal

devoted to the disease of

EAR, NOSE AND THROAT

Official organ for the American Laryngological

Rhinological and Otological Society

Price $\$ 15.00$ per year Canada $\$ 15.50$ per year

Foreign $\$ 16.00$ per year

Max A. Goldstein, M.D.

THEODORE E. WALSH, M.D.

FOUNDER

EDITOR

640 SOUTH KINGSHIGHWAY

SAINT LOUIS 10, MO.

For advertisement space in this Journal

apply to:

\section{HEADLEY BROTHERS LTD.}

109 Kingsway London WC2

Please mention The Journal of Laryngology and Otology when replying to advertisements 


\title{
EIGHT NEW BOOKS FOR YOUR PROFESSIONAL LIBRARY
}

\section{Cash with Order outside USA and Canada}

\section{We pay postage and guarantee delivery}

AUDIOLOGICAL EVALUATION OF THE PEDIATRIC PATIENT by Maurice H. Miller and Ira A. Polisar, both of State University of New York, Brooklyn, N.Y. Emphasis is on various diagnostic techniques for hearing evaluations. The personnel, equipment, and physical plant for proper performance of these procedures are described. The technique is then evaluated as to its over-all clinical value and related to other as jects of the total evaluation. Detailed case histories illustrate the contribution made by various procedures. March '64, 132 pp., 8 il. (Amer. Lec. Speech and Hearing edited by Robert West), $\$ 5.75$

MENINGIOMAS INVOLVING THE TEMPORAL BONE: Clinical and Pathological Aspects by George T. Nager, The Johns Hopkins Univ., Baltimore, $M d$. Points the way toward early recognition of the condition and better clinical and surgical care. Part $I$ is concerned with present-day concepts of endocranial meningiomas in generalembryogenesis, pathogenesis, sites of origins, local behaviour, and gross and microscopic characteristics. In Part $I I$ seven cases of meningiomas with involvement of the temporal bone are presented in detail. Part $I I I$ is devoted primarily to regional behaviour, life history, and surgical end results. Jan. 64', 192 pp., 129 il., $\$ 11.50$

EAR, NOSE AND THROAT FOR THE GENERAL PRACTITIONER by Albert P. Seltzer, Univ. of Pennsylvania, Philadelphia, Pa. This book was especially prepared to show by example how diseased conditions in widely different parts of the body do have either their primary origin or a secondary relationship in abnormal conditions in the ear, nose and throat cavities and in their nearby tissues. The author deals primarily with the ear, nose and throat but includes the accessory nasal sinuses. A comprehensive text with special significance for medical students entering the field of ear, nose and throat. March '64, 244 pp., $\$ 7.75$
MANUAL OF SURGICAL TECHNIQUE by Warner F. Bowers, New York Med. Coll., New York City; Thomas $\mathbf{H}$. Hewlett, Fitzsimons General Hospital, Denver, Colo.; and George J. Thomas, Brooke General Hosp., Ft. Sam Houston, Texas. Oct.' 63,328 pp. $\left(8 \frac{1}{2} \times 11\right), 977$ il., $\$ 14.00$

BIOPHYSICS OF THE EAR $b y$ F. L. Dittrich, Univ. of Geneva, Geneva, Switzerland. Oct. '63, 136 pp. 73 il.l (Amer. Lec. Biochemistry \& Biophysics edited by W. Bladergroen, Jr.) $\$ 6.75$

MANAGEMENT OF ORAL EMERGENCIES by Daniel $M$. Laskin, Univ. of Illinois, Chicago, Ill. Jan. '64, 128 pp., 52 il., 6 tables, $\$ 5.50$

DISEASES OF MEDICAL PROGRESS: A Contemporary Analysis of Illness produced by Drugs and Other Therapeutic Procedures (2nd Ed.) edited by Robert H. Moser, U.S. Army Tripler General Hosp., Honolulu, Hawaii. (With 12 Contributors), Feb. '64, 572 pp., $\$ 19.75$

ILLUSTRATED SPEECH ANATOMY by William $M$. Shearer, Northern Illinois Univ., DeKalb, Ill. Sept. '63, 96 pp., 48 il., $\$ 4.75$

\section{CHARLES C THOMAS - Publisher}

\author{
301-327 EAST LAWRENCE AVENUE
} Send for our SPRINGFIELD * ILLINOIS * USA 

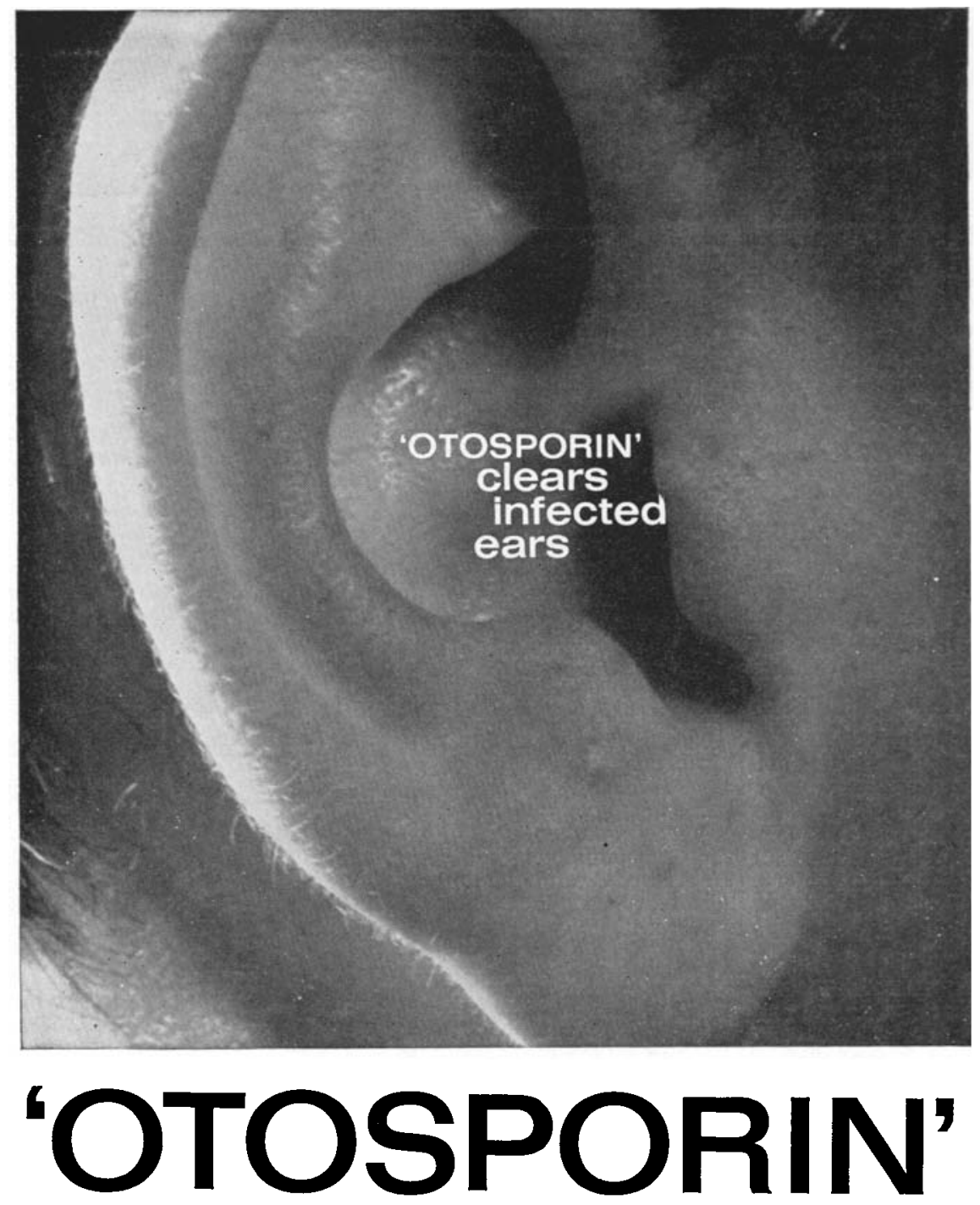

The modern method of treatment in otitis externa, chronic suppurative otitis media, and infected mastoid cavities, is 'Otosporin' Drops. 'Otosporin' is an aqueous suspension containing neomycin and polymyxin B which are together effective against practically all the bacteria found in ear infections. In addition, it contains hydrocortisone to reduce inflammation and swelling, thereby providing easier access for the antibiotics.

\section{'OTOSPORIN' brand Drops issued in bottles of $5 \mathrm{ml}$.}

BURROUghS WELLCOME \& CO. (THE WELLCOME FOUNDATION LTD.) LONDON

Please mention The Journal of Laryngology and Otology when replying to advertisements 